\title{
HOW CORPORATE GOVERNANCE AND CASH HOLDINGS AFFECT EARNINGS QUALITY AND FIRM VALUE
}

\author{
Tri Lestari \\ trilestari.untirta@gmail.com \\ Imam Abu Hanifah \\ Universitas Sultan Ageng Tirtayasa \\ Jl. Raya Jakarta Km 4 Pakupatan, Kota Serang, Banten 42124
}

received: 19/2/19; revised: 13/10/19; approved: 29/6/20

\begin{abstract}
This study analyzes the impact of corporate governance (CG) and cash holdings (CH) on earnings quality and the implication on firm value. We hypothesize that earnings quality mediate the impact of $C G$ and $C H$ on firm value. Banking sector was chosen as the object of research because this sector is quite vulnerable to the global financial crisis. The population consists of banking companies listed on the Indonesia Stock Exchange (IDX) in the period of 2013-2017. Data were analyzed by multiple regression models using SPSS software. The results show that CG and CH have a significant effect on earnings quality. But this influence shows the opposite direction of expectations. Banks with good CG have lower earnings quality, and banks with high $\mathrm{CH}$ show better earnings quality. Only $C G$ that has a significant effect on firm value with negative direction. This study did not find the mediating effect from both variables.
\end{abstract}

Keywords: self-assessment; corporate governance; cash holdings; firm value; earnings quality

\section{INTRODUCTION}

Investors concern to Firm's value because it reflects the company's performance. Investor valuation of the firm can be observed through stock price movements that are being transacted on the exchange. Factors that influence stock prices include internal factors such as information on increases in net income and expansion plans and external factors (systemic risk) such as government policies, interest rates, rupiah exchange rates, stock price indices, and influences from foreign exchanges (Isti'adah, 2015).

Earnings is very important information in financial reporting because earnings is a measure of company performance. Earnings information shows management performance. In addition, earnings information can also help estimate the ability of representative earnings in the long run, forecast earnings, assess risks in investing or credit, predict future cash flows and have a large influence on users in making decisions (Tohir and Yuyetta, 2013).

Another internal factor that concerns the investors is the implementation of CG, especially for banking sector. Bank Indonesia issued Bank Indonesia Regulation No.13/1/PBI /2011 concerning the evaluation of the soundness level of commercial banks. This regulation requires the Bank to conduct self-assessment. In this study, the self assessment score is using as the proxy of corporate governance implementation.

The factor that has also been a concern of researchers in recent years is the cash holding policy. Determination of cash holding at the optimal point is very necessary because cash is the element of working capital that is most needed by the company to fulfill the company's operational activities. Both the holding of excess cash holding and the holding of too little cash balance (cash shortfall) have consequences for companies and shareholders (Bayu and Septiani, 2015).

This study made a new contribution by using different measurement indicators for the CG implementation variables compared to previous studies. This study uses ranking self assessment results as an indicator for implementing CG. By using the results of the self assessment, it is expected to be able to describe the implementation of CG more comprehensively because it includes all elements of CG.

Bistrova and Natalja (2012), found that companies that have good governance will minimize the manipulation of financial statements. Research conducted by Meeampol, et. al. (2013) prove that companies that implement CG well will minimize the occurrence of earnings management so that the quality of earnings will increase. Yahya (2014) also found that the IICG (Indonesia Institute for corporate 
governance) score had a significant and positive effect on earnings quality. These results indicate that the better the implementation of CG shows the better corporate governance, so that the expected quality of earnings will be well assessed by investors.

Regarding the cash holdings policy, managers can use it to minimize external funding and company operations. Because of its highly liquid, cash holdings are very easily misused by managers for their personal interests. Therefore the cash holdings policy is used to influence the behavior of managers to conduct earnings management. Talebnia and Hadiseh (2012) found that companies with high levels of free cash flow faced agency problems, which could lead to managers becoming increasingly motivated to practice earnings management. Mambraku and Hadiprayitno (2014) also found that the higher cash holdings will increase the tendency of earnings management behavior. While the research of Ismail (2015) found that companies with high excess cash have higher earnings quality.

Roy (2016) argue that well implemented CG can affect firm performance in two different ways. First, strong CG may lead to high share price multiples. Second, good CG may reduce the expected return on equity to the extend that it reduce shareholders monitoring and auditing costs, leading to lower cost of capital. Herawaty (2008), Siagian, et. al. (2013), Lestari, et. al. (2014), Abdallah and Ismail (2017) and Nazir and Afza (2018) found a positive relation between CG and the value of the company. However, Darko, et. al., (2018) found no significant relation.

Previous research found inconsistence results on the effect of cash holding on firm value. Lee and Few Lee (2008) and Darko, et. al., (2018) found a negative relation between the level of cash holdings and firm value. Sola, et. al. (2011) and Nhan and Ha (2016) found an inverted U-shaped relationship between cash holding and firm value. While research conducted by Isshaq (2009) and Putri \& Achmad (2011) found insignificant effect of cash holdings on firm value.

Profit is said to be of high quality if the profits reported by the company can be used by users of financial statements to make the right decisions or can be used to predict stock prices and returns. The quality of earnings becomes low if in presenting profits does not match the actual profit so that the information obtained from the earnings report becomes biased and the impact misleads the users of financial statements in making decisions. The low quality of earnings will have an impact on the decline in the value of the company in the future.

Lestari, et. al. (2014) found that earnings quality has an influence on firm value. The more quality earnings reported, it will minimize the decision making mistakes of financial statement users, so that the company's value is maintained. Quality earnings can also explain the company's actual market value because for companies that issue shares on the capital market the price of shares traded on the stock is an indicator of the company's value.

The quality of earnings in financial statements is influenced by the company's seriousness in applying $\mathrm{CG}$ principles. In the banking sector, to ensure that the CG has been implemented properly, it can be seen from the ranking obtained in the CG self assessment report. Due to the weak implementation of $\mathrm{CG}$, it will cause a conflict of interest that occurs in the bank organization. Conflict of interest occurs due to differing views between the agent and the principal. Differences in interests between the two parties often lead to agency conflicts.

Yahya's research (2014) proves that CG has an indirect effect on firm value by passing earnings quality as an intervening variable. Based on the results of the study, earnings quality mediates the effect of $\mathrm{CG}$ on firm's value.

Similarly, the influence of cash holdings on firm's value. Lee and Few Lee (2008) found that high cash holdings would reduce the value of the company. In companies with weak corporate governance, control of the use of cash will tend to be weak. Companies with high cash holdings will face agency problems more (Talebnia and Hadiseh, 2012), whose effect will motivate management to conduct earnings management. So companies with high cash holdings will tend to have low earnings quality.

Some studies confirm the influence of earnings management on firm value (Lestari, et. al., 2014 and Yahya, 2014). The more quality of earnings then it will have the value of information that is useful for the decision making of investors. So that earnings quality will be better able to explain the market value of the company.

\section{METHODS}

The data used in this study were obtained from the bank's annual report downloaded from www.idx. co.id and reports on the implementation of CG banks obtained from the websites of each bank.

Firm's value is measured as the ratio of price to book value of equity (PBV). This study uses the stock price at the date of the annual report published. Measure of $\mathrm{CG}$ uses a $\mathrm{CG}$ ranking self assessment. The ranking of CG self assessment factors is a category of assessment of the implementation of $\mathrm{CG}$ principles, which contains eleven assessment factors for implementing CG. The assessment results in grades 1 to 5 . Rank 1 shows the best implementation of CG, respectively until rank 5 is the worst. Cash holdings are measured as the ratio of cash and equivalent to the total assets at the end of period.

Earnings quality is measured by detecting earnings management. Earnings management is proxied using 
the discretionary loan loss provision (DLLP) used by Kanagaretnam et al. (2003). The use of discretionary loan loss provisions is considered suitable for measuring the level of earnings management in banking sector and has been widely used in research as a proxy for earnings management in the banking sector (Kanagaretnam, et. al., 2003; Cheng, et. al., 2011; Zeptian and Rohman, 2013).

$$
\operatorname{LLP}_{\mathrm{it}}=\alpha+\beta_{1} \mathrm{NPL}_{\mathrm{it}}+\beta_{2} \mathrm{CHNPL}_{\mathrm{it}}+\beta_{3} \mathrm{CHLoan}_{\mathrm{it}}+\mathrm{e} \ldots . .(1)
$$

Where:

LLP $_{\mathrm{i}, \mathrm{t}} \quad$ : loan loss provisions

$\mathrm{NPL}_{\mathrm{i}, \mathrm{t},-1} \quad$ : non performing loans at beginning

CHLOAN $_{\mathrm{i}, \mathrm{t}}$ : change of loan (LOANi,t-LOANi,t-1)

CHNPL $_{i, t}$ : change of NPL (NPATi,t-NPATi,t-1)

All variables in the DLLP estimation model are divided by total loan in the beginning of period. The residual obtained from the LLP regression model is a DLLP value, which then takes its absolute value.

This study used path analysis by estimating two regression models, as follow:

$\operatorname{DLLP}_{\mathrm{it}}=\alpha+\beta_{1} \mathrm{CG}_{\mathrm{it}}+\beta_{2} \mathrm{CH}_{\mathrm{it}}+\beta_{3} \mathrm{RoA}_{\mathrm{it}}+\mathrm{e}$

$\mathrm{PBV}_{\mathrm{it}}=\alpha+\beta_{1} \mathrm{CG}_{\mathrm{it}}+\beta_{2} \mathrm{CH}_{\mathrm{it}}+\beta_{3} \mathrm{DLLP}_{\mathrm{it}}+\beta_{3} \mathrm{RoA}_{\mathrm{it}}+\beta_{4}$ Size $_{\text {it }}+\beta_{4} \operatorname{Lev}_{\text {it }}+\beta_{4}$ Age $_{\text {it }}+\mathrm{e}$

Where:

DLLP: discretionary loan loss provision.

CG : score of corporate governance self-assessment, the smaller score indicates a better CG implementation.

$\mathrm{CH}$ : cash holdings, the ratio of cash and cash equivalent to total assets.

RoA : return on asset.

PBV : price to book value.

Size : log natural of total assets.

Lev : leverage, measured as total liabilities scaled by total assets

Age : the actual year of bank listing on IDX up to the observation year

This study regress CG, $\mathrm{CH}$ and RoA on DLLP for model (1), and then regress of CG, CH, DLLP and some control variables on PBV for model (2). To analyze the mediating effect, this study use the sobel test. Since the DLLP variable does not meet the normal distribution requirements, therefore this variable is then taken its natural Log value.

\section{RESULTS}

The results of the regression model (1) show that $C G$ has a regression coefficient of $-0,361$ with t test and $-2,199$, sig. 0,029 . It can be concluded that hypothesis 1 is supported, good corporate governance has a significant effect on earnings quality. $\mathrm{CH}$ has a regression coefficient of $-2,928$ with $t$ test $-1,684$ and sig. 0.094. This result is significant at the $\alpha$ level of $10 \%$. Then it can be concluded that hypothesis 2 is supported, cash holdings have a significant effect on earnings quality.

Results from regression model (2), CG has a regression coefficient of 0,246 with t test 2,215 and sig. 0,028 . Then it can be concluded that hypothesis 3 is supported, good corporate governance has a significant effect on firm value. $\mathrm{CH}$ has a regression coefficient of $-0,933$, $t$ test $-0,799$, and sig 0,425 . Then it can be concluded that hypothesis 4 is not supported, cash holdings have no significant effect on firm value. Earnings quality (DLLP) has a regression coefficient of $0,062, t$ test 1,112 . and sig. 0,268 . Then it can be concluded that hypothesis 5 is not supported, earnings quality does not have a significant effect on firm value.

Meanwhile, the results for the control variable, only the AGE variable shows a significant effect with the value of $t$ calculated at $-2,733$ and the significance value of 0,007 . So that this result can be interpreted that the longer the bank is listed on the stock, the higher the bank's value.

Testing of hypothesis 6 is done by the sobel formula and is calculated using the available sobel online calculator. The results of the sobel test calculation show that earnings quality variables do not mediate both the effect of cash holdings on firm value (Sobel test stat: $-0,906$; sig. 0,364$)$ and on the effect of good corporate governance on firm value (Sobel test stat: $-1,039$; sig 0,298 ) Thus, hypothesis 6 cannot be supported.

\section{DISCUSSION}

The results of regression model (1) show that CG has a significant effect on earnings quality. The regression coefficient of this variable is negative, this can be interpreted that this variable has the opposite effect. If the value of the CG variable increases, the value of the earnings quality will decrease. The CG variable in this study was measured using the values obtained from the CG application self assessment report on the sample. The smaller the value in this variable shows the better the CG implementation at the bank. Meanwhile earnings quality is measured by calculating the value of discretionary loan loss provisions (DLLP), which is the greater the value of DLLP assumed the lower the quality of profits. Thus, the results infer that the better the self assessment CG, the bank has a lower quality of earnings.

From these results, it can be interpreted that the good implementation of CG does not guarantee the quality of the financial statements presented by the bank will be better. The quality of financial statements here is seen from the perspective of earnings quality. This study uses measurements of earnings quality 
by calculating abnormal or descretionary Loan Loss provisions (DLLP). Quality earnings will contain low DLLP.

The findings of this study is not in line with the findings of Bistrova and Natalja (2012), Yahya (2014) and Meeampol, et. al. (2013) who found that good CG implementation would be able to minimize earnings management behavior. For research with the object of banking, Tohir and Yuyetta (2013) only found institutional ownership (as one of the CG proxies) that had an effect on earnings management. Earnings management in the study was measured using Jones model accrual earnings management.

Different results found in this study may caused by the different indicators used from previous studies. Previous research generally used the measurement of the CG mechanism as a proxy approach to implementing CG. Diverse measurement of earnings management can also lead to different findings.

The model (1) regression results (Table 1) show that $\mathrm{CH}$ has a significant effect on earnings quality. Regression coefficient indicates the direction of negative influence. $\mathrm{CH}$ represents the management policies related to the company's cash level. The higher the value of $\mathrm{CH}$, the higher the amount of cash and cash equivalents held in the company.

Some studies find that higher cash holdings will increase management's tendency to make earnings management. This indicates that the cash holdings policy affects management's behavior to conduct earnings management. Where, in this study earnings management is measured by seeing the magnitude of DLLP. This study supports the results of Talebnia and Hadiseh (2012) and Mambraku \& Hadiprayitno (2014).

CG has an effect on firm value measured as PBV, where the stock price taken is the closing stock price on the day of publication of the company's annual report. The sign on the regression coefficient is positive. These results can be interpreted as the greater the value of CG self assessment the greater the value of the bank PBV. This is also on the contrary to expectation. When the implementation of good corporate governance is getting better, it can not increase the bank's stock price.

This research is not in line with the findings of Siagian, et. al. (2013), Dianawati and Fuadati (2016), Roy (2018), and Nazir and Afza (2018). However, the indicators used by the previous researchers generally use the CG mechanism as a proxy for the size of $C G$ implementation. While the findings of Perdana and Raharja (2014), only managerial ownership and the proportion of independent commissioners have an influence on the value of the company.

Yahya (2014) using the IICG index indicator as a measure of $\mathrm{CG}$ implementation also found no positive influence on firm value. The results of this study are in line with the findings of Devi (2013) who also found a negative effect of CG on firm value. Putri and Achmad
(2011) also found a CG mechanism with managerial ownership and institutional ownership measures that negatively affected firm value.

From the regression model (2), it can be seen $\mathrm{CH}$ has no significant effect on firm value. It was found that the cash and cash equivalents policies held by the company were not able to influence the market valuation of the bank. This is proven statistically by the results of the $\mathrm{CH}$ variable regression not significantly affecting PBV.

From these results, it can be seen that the market or investors do not pay too much attention to the cash holdings policy contained in the company's financial statements. This result is in line with the findings of Isshaq (2009) and Putri and Achmad (2011) who also found a non-significant negative effect of cash holdings on firm value.

The results of this study do not support the findings of Lee and Lee (2008) who found a significant negative effect of cash holdings on firm value. While Sutrisno's (2017) research actually found a positive relationship between cash holdings and company value.

In the regression results of model (2) at table 2, it can be seen that the earnings quality variable has no significant effect on firm value. In this study, it was found that the quality of earnings as measured by the magnitude of DLLP was not able to influence market valuation of banks. This is proven statistically by the results of the DLLP variable regression not significantly affecting PBV.

This result is in line with the findings of Putri and Rohman (2012). The study also did not find a significant effect on the quality of earnings on firm's value. However, the findings of this study do not support the results of Lestari, et. al., (2014) who found a significant effect of earnings quality on firm's value.

This insignificant influence indicates that the quality of earnings is not overlooked by the market, therefore the level of earnings quality in financial statements is not reflected in the stock price which is the basis for measuring companies' value. Another possibility is that there are other factors such as macroeconomic factors that have a more dominant influence on stock price movements. Market conditions that are not yet efficient markets can be a cause of lack of information on earnings at share prices in the Indonesian market.

The results of path analysis show that mediating earnings quality on the effect of CG and cash holdings on firm's value is not supported. This is because the direct influence of earnings quality on firm value is not significant, so this variable is also not able to mediate the influence of CG and cash holdings on firm's value.

\section{CONCLUSIONS}

From the results of data analysis and discussions described in the previous chapter, it can be concluded that there is a negative effect of CG on earnings quality. 
Banks with good CG ratings tend to have lower earnings quality. $\mathrm{CH}$ has a positive effect on earnings quality. This influence also shows an influence in a positive direction, banks with high free cash flow have better earnings quality. CG has a negative effect on firm value, while $\mathrm{CH}$ and DLLP have no effect on firm's value. Finally, this study did not find a mediating effect by earnings quality.

Further research is recommended to be more careful in the selection of the research period, especially related to the measurement of stock market prices. It is necessary to consider the influence of macro factors that may have a more dominant influence on stock prices for certain period. For this reason, it is necessary to add control variables to anticipate these influences or can also issue samples in periods where macro influences are more dominant.

\section{REFERENCES}

Abdallah, A. A.N. and Ismail, A. K. 2017. Corporate Governance Practices, Ownership Structure, and Corporate Performance in the GCC Countries. Journal of International Financial Markets, Institutions and Money. Vol. 46 (January), pp. 98115.

Bayu, A. and Septiani A. 2015. Pengaruh Cash Holding Terhadap Nilai Perusahaan (studi empiris terhadap perusahaan manufaktur yang terdaftar di BEI tahun 2011 - 2013). Diponegoro Journal of Accounting. Vol 4, No 4.

Bistrova, J. and Natalja L. 2012. Quality of Corporate Governance System and Quality of Reported Earnings: Evidence From CEE Companies. Journal of Economics and Managements. Vol. 17, No. 1.

Cheng, Q., Warfield, T., Ye, M. 2011. Equity Incentives and Earnings Management: Evidence from The Banking Industry. Journal of Accounting, Auditing and Finance, Vol.26, No.2, pp. 317-349.

Darko, D. A, Bonsu, B. A., Famiyeh, S., Kwarteng, A., and Goka, Y. 2018. Governance Structures, Cash Holdings and Firm Value on teh Ghana Stock Exchange. Corporate Governance: The International Journal of Business in Society. https:// doi.org/10.1108/CG-07-2017-0148.

Devi, A., 2013. Pengaruh Mekanisme Good Corporate Governance (GCG) dan Struktur Kepemilikan Terhadap Nilai Perusahaan (Studi Empiris Pada Perusahaan Perbankan Yang Terdaftar di Bursa Efek Indonesia 2010-2013). Jurnal Tekun, 4(02), pp.199-211.

Dianawati, Cici Putri, and Fuadati, Siti Rokhmi. 2016. Pengaruh Corporate Social Responsibility dan Good Corporate Governance Terhadap Nilai Perusahaan: Profitabilitas Sebagai Variabel Intervening. Jurnal Ilmu dan Riset Manajemen : Volume 5, Nomor 1.

Herawaty, Vinola. 2008. Peran Praktek Corporate
Governance sebagai Moderating Variable dari Pengaruh Earnings Management terhadap Nilai Perusahaan, Jurnal Akuntansi dan Keuangan, Vol. 10, No. 2, pp. 97- 108.

Ismail, Redhwan Al-dhamari Ku Nor Izah Ku. 2015. Cash holdings, political connections, and earnings quality. International Journal of Managerial Finance, Vol. 11 Iss 2 pp. $215-231$.

Isshaq, Zangina. 2009. Corporate governance, ownership structure, cash holding, and firm value on the Ghana stock Exchange. TheJournal of Risk Finance, Vol.10 No.5, pp. 488-499. www.emeraldinsight.co.id.

Isti'adah, U., 2015. Pengaruh Mekanisme Corporate Governance terhadap Nilai Perusahaan dengan Kulaitas Laba sebagai Variabel Intervening. Skripsi. Universitas Negeri Yogyakarta.

Kanagaretnam, K., Lobo, G. J., and Mathieu, 2003. Managerial incentives for income smoothing through bank loan loss provisions. Review of Quantitative Finance and Accounting, Vol. 20 No. 1, pp. 63-80.

Lee, Wai Kin and Few Lee, Cheng. 2008. Cash Holding, Corporate Governance Structure and Firm Valuation. Nanyang Business School, Singapore.

Lestari, N.B., Khafid M., and Anisykurlillah I. 2014. Pengaruh Good Corporate Governance terhadap Nilai Perusahaan dengan Kualitas Laba sebagai Variabel Intervening. Accounting Analysis Journal. Universitas Negeri Semarang.

Mambraku, M.E., and Hadiprayitno, P.B. 2014. Pengaruh Cash Holding dan Struktur Kepemilikan Manajerial terhadap Income Smoothing. Diponegoro Journal Of Accounting, Vol. 3, No. 2.

Meeampol, S., Vimol R., Phanthipa S., and Ausa W. 2013. The Relationship between Corporate Governance and Earnings Quality: A Case Study of Listed Companies in the Stock Exchange of Thailand (Set). Active Citizenship by Knowledge Management \& Innovation Learning. International Conference Zadar, Croatia.

Nazir, M. S., and Afza, T. 2018. Does Managerial Behavior of Managing Earnings Mitigate the Relationship between Corporate Governance and Firm Value? Evidence from an Emerging Market. Future Business Journal. Vol. 4, pp. 139-156.

Nhan, D. T.T., and Ha, P. 2016. Cash Holding, State Ownership and Firm Value: The Case of Vietnam. International Journal of Economics and Financial Issues, Vol. 6, (S6), pp. 110-114.

Perdana, R.S and Raharja. 2014. Analisis Pengaruh Corporate Governance terhadap Nilai Perusahaan. Diponegoro Journal of Accounting. Vol. 3 No. 3.

Putri, R. K., and Achmad, T. 2011. Analisis Pengaruh Corporate Governance, Struktur Kepemilikan, dan Cash Holdings Terhadap Nilai Perusahaan, Jurnal Liquidity,Vol.12, No.4, pp. 92-98.

Puteri, P. A., and Rohman, A. 2012. Analisis pengaruh 
Investment Opportunity Set (IOS) dan Mekanisme Corporate Governance terhadap Kualitas Laba dan Nilai Perusahaan. Diponegoro Journal of Accounting. Vol. 1, No. 2, pp. 1-14. Universitas Diponegoro.

Roy, Amitava. 2016. Corporate Governance and Firm Performance: A Study of Indian Listed Firms. Metamorphosis. Vol. 15, No.1,pp. 31-46.

Siagian, F., Sylivia V. Siregar, dan Yan Rahadian. 2013. Corporate Governance, Reporting Quality, and Firm Value: Evidence from Indonesia. Journal of Accounting in Emerging Economies. Vol. 3 No. 1, pp. 4-20. Emerald Group Publishing Limited

Sola, C. M, Teruel, P.G., and Solano, P. M. 2011. Corporate Cash Holding and Firm Value. Applied Economics, Vol. 45, No. 2, pp. 161-170.

Sutrisno, B. 2017. Hubungan Cash Holding dan Nilai Perusahaan di Indonesia. Jurnal Dinamika Akuntansi dan Bisnis. Vol. 4(1), 2017, pp 45-56.
Universitas Muhammadiyah Jakarta.

Talebnia, G. and Hadiseh, D. 2012. Cash holdings and Income smoothing: evidence from Tehran Stock Exchange, American Journal.

Tohir R., and Yuyetta E. N. A. 2013. Pengaruh Struktur Corporate Governance pada Kualitas laba dengan Intellectual Capital Disclosure sebagai Variabel Intervening. Diponegoro Journal of Accounting. Vol. 2, No.4, hal. 1-10. Universitas Diponegoro.

Yahya, Y. N. 2014. Pengaruh Skor IICG terhadap Nilai Perusahaan dengan Kualitas Laba sebagai Variabel Intervening. Jurnal Ilmu \& Riset Manajemen. Vol. 3 No. 9. Sekolah Tinggi Ilmu Ekonomi Indonesia (STIESIA) Surabaya.

Zeptian, A and Rohman, A. 2013. Analisis Pengaruh Penerapan Corporate Governance, Struktur Kepemilikan, dan Ukuran Perusahaan Terhadap Manajemen Laba Pada Perbankan. Diponegoro Journal of Accounting. Vol. 2, Nomor 4, pp. 1-11.

Tabel 1.t Statistical Test

\begin{tabular}{lcccc}
\hline & \multicolumn{2}{c}{ Model (1) } & \multicolumn{3}{c}{ Model (2) } \\
\cline { 2 - 5 } & Standardized coefficients & Sig. & Standardized coefficients & Sig. \\
\hline CH & $-0,129$ & 0,094 & $-0,064$ & 0,425 \\
CG & $-0,174$ & 0,029 & 0,185 & 0,028 \\
LnDLLP & & & 0,097 & 0,268 \\
LEV & & $-0,115$ & 0,150 \\
SIZE & & $-0,075$ & 0,346 \\
AGE & & $-0,244$ & 0,007 \\
ROA & & 0,112 & 0,206 \\
\hline
\end{tabular}

$\mathrm{CH}$ is the ratio of cash and cash equivalent to total assets, $\mathrm{CG}$ is the score of corporate governance self assessment, LnDLLP is the log natural of discretionary loan loss provision, LEV is total liabilities scaled by total assets, SIZE is the log natural of total assets, AGE is the actual year of bank listing on IDX up to the observation year, and ROA is net income scaled by average total assets. 